Asian J Agric \& Biol. 2021(3). $\mathrm{AJAB}$ DOI: $10.35495 / a j a b .2020 .07 .412$

Original Article

\title{
Changes on the heat shock protein 70 (HSP70) in water buffalo spermatozoa revealed the capacitation like event in cryopreservation
}

\author{
Maylem Excel Rio S. ${ }^{1,3}$, Rivera Shanemae M. ${ }^{1 *}$, Ramos Gerald E. ${ }^{1}$, Atabay Edwin C. ${ }^{1,2}$, Venturina Emma V. ${ }^{2}$, \\ Atabay Eufrocina P. ${ }^{1}$ \\ ${ }^{1}$ Reproduction and Physiology Section, Philippine Carabao Center, National Headquarters and Genepool, Science \\ City of Muñoz, Nueva Ecija, Philippines \\ ${ }^{2}$ Philippine Carabao Center at Central Luzon State University, Science City of Muñoz, Nueva Ecija, Philippines \\ ${ }^{3}$ Oklahoma State University, Stillwater, Oklahoma, USA
}

\begin{tabular}{|c|c|}
\hline $\begin{array}{l}\text { Received: } \\
\text { July 23, } 2020\end{array}$ & \multirow{6}{*}{$\begin{array}{l}\text { Abstract } \\
\text { Heat Shock Protein } 70 \text { (HSP70) induction helps alleviate the adverse effects of several } \\
\text { types of stress in the cells. It can also play a significant role in sperm protection and } \\
\text { survival during the extreme conditions of the semen cryopreservation process. The } \\
\text { present study was conducted to investigate the role of this protein in spermatozoa of } \\
\text { water buffalo by analyzing the changes in its gene expression, protein induction, and } \\
\text { distribution after cryopreservation. Differences in HSP70 mRNA and protein levels } \\
\text { between fresh and frozen semen samples were determined through real-time PCR and } \\
\text { western blot analysis, respectively. Cellular localization patterns of HSP70 in the } \\
\text { different sample groups were then detected in an indirect immunofluorescence assay. } \\
\text { Lastly, the average sperm motilities of the semen sample groups were evaluated and } \\
\text { compared. Results showed that the HSP70 mRNA expression decreased by fifty } \\
\text { percent (P<0.05) while the protein level significantly rose by sixty percent (P<0.05) in } \\
\text { the frozen sample group. The localization of HSP70 protein in the sperm head also } \\
\text { shifted from the equatorial segment in the fresh sample group to the post-acrosomal } \\
\text { region in frozen semen samples. Moreover, the average sperm motility appeared to } \\
\text { fluctuate with the mRNA level and comparably decreased by fifty percent (P<0.05) in } \\
\text { the frozen sample group. These changes on the HSP70 in spermatozoa exhibited the } \\
\text { adverse effects of the underlying capacitation-like event in the cryopreservation } \\
\text { process. Overall, these findings presented a valuable insight into the current buffalo } \\
\text { semen cryopreservation technique and a potential approach to its improvement. } \\
\text { Keywords: Cryopreservation, HSP70, Spermatozoa, Water Buffalo } \\
\text { How to cite this: } \\
\text { Maylem ERS, Rivera SM, Ramos GE, Atabay EC, Venturina EV and Atabay EP, 2021. } \\
\text { Changes on the heat shock protein } 70 \text { (HSP70) in water buffalo spermatozoa revealed } \\
\text { the capacitation like event in cryopreservation. Asian J. Agric. Biol. 2021(3): } \\
202007412 \text {. DOI: https://doi.org/10.35495/ajab.2020.07.412 }\end{array}$} \\
\hline & \\
\hline & \\
\hline & \\
\hline & \\
\hline $\begin{array}{l}\text { *Corresponding author email: } \\
\text { shanemoranterivera @gmail.com }\end{array}$ & \\
\hline & \\
\hline
\end{tabular}




\section{Introduction}

Semen cryopreservation is an integral process of most assisted reproduction technology, like artificial insemination and in-vitro fertilization. It allows the maximum and indefinite utilization of germplasm for the breeding of agriculturally important animals and the conservation of genetic materials. However, the extreme state at which the cells are sustained has been shown to cause detrimental stresses (Watson, 2000). The cold and osmotic shock in particular cause membrane destabilization (Watson, 2000; Morris et al., 2012), lipid peroxidation (Morris et al., 2012; Olszewska-Slonina, 2013), and protein aggregation (Cao et al., 2003) in cryopreserved sperm. If these cellular changes are not controlled, they can further trigger a cascade of irreversible reactions that highly resemble the process of sperm capacitation (Cormier and Bailey, 2003; Talukdar et al., 2016). This 'capacitation-like' event renders the spermatozoa susceptible to further degradation of the cell membrane (Harrison, 1996) and external influences (Watson, 2000), consequently limiting the reproductive lifespan of cryopreserved semen (Ellington et al., 1999) and compromising its overall quality (Watson, 2000, Pini et al., 2018). Even the fertilizing ability of the spermatozoa can be reduced (Cormier and Bailey, 2003). Indeed, it posed a huge constraint in the success of semen cryopreservation. The Heat Shock Protein (HSP) family had been demonstrated to confer cellular tolerance against such types of harmful traumas and protect the cells from degradation (Guerriero and Raynes, 1990). Specifically, higher expression of HSP70 in a subpopulation resulted in a significantly lower percentage of reacted, or 'capacitated', spermatozoa (Holt et al, 2015; Mohamad et al., 2018). Several studies suggested that HSP70 may have additional roles in sperm aside from stress tolerance. For instance, its intracellular level had been observed in many cases to change proportionally with sperm motility (Zhang et al., 2015; Huang et al., 2000). Furthermore, HSP70 had been previously reported to play a key role in gamete interaction by serving as an important binding site (Matwee et al., 2001). This was later supported in a separate study wherein the lack of HSP70 transcript in the sperm effectively inhibited the process of fertilization (Nixon et al., 2015).

However, what is known on the effect of cryopreservation on HSP70 in water buffalo spermatozoa remains very limited and uncertain. This knowledge can unravel a new perspective on semen cryobiology and can have valuable implications in the optimization of the cryopreservation technique. The present study was therefore undertaken to investigate the changes in the gene expression, protein synthesis, and distribution of HSP70 in water buffalo spermatozoa after semen cryopreservation. The change in the motility of the samples was also considered and examined to monitor the quality of the cells.

\section{Material and Methods}

The study was conducted for several months from October 2018 to June 2019. Semen collection was done simultaneously with the routine semen collection and processing of the National Bull Farm, Philippine Carabao Center at Central Luzon State University, Carranglan, Nueva Ecija, Philippines. Samples were then taken to the Reproduction and Physiology Section Laboratory, Philippine Carabao Center National Headquarters and Genepool for subsequent laboratory procedures and analyses.

\section{Test samples}

A total of 10 healthy water buffaloes (Bubalus bubalis) sperm donor bulls were selected as the sample source. They were maintained with uniform feeding and management following the good animal husbandry practices (GAHP) of the institution. Two collections of semen using an artificial vagina were conducted with an interval of seven days apart, during which two ejaculates were obtained from individual donor bulls. Each ejaculate first underwent the sperm motility evaluation and then pooled into one sample.

\section{Experimental group}

Samples were divided into two groups, the Fresh and Frozen group, which were prepared and processed separately. The fresh group consisted of the $1 \mathrm{ml}$ pooled semen samples obtained from individual bulls that were extracted immediately after collection. The other sample group, the Frozen group, was first subjected to the standard cryopreservation process using a tris-egg yolk-glycerol (TEY) extender (Mamuad and Venturina, 2013). These were kept in liquid nitrogen for approximately sixty days and then evaluated again for post-thaw sperm motility before extraction. Since frozen samples were extended, $5 \mathrm{ml}$ semen was used for extraction and sample preparation. 


\section{Gene expression analysis}

The extraction protocol of Rajoriya et al. (2014) for total RNA isolation using Trizol® Reagent (Thermo Fisher Scientific, USA) heated at $60{ }^{\circ} \mathrm{C}$ was adapted with minor modifications. After isolation, $2 \mathrm{ml}$ of pooled semen samples were dehydrated with alcohol and centrifuged consistently at $12000 \mathrm{rpm}$ for $15 \mathrm{~min}$ at $4{ }^{\circ} \mathrm{C}$. The samples were then air-dried for at least two hours before rehydration with $20 \mu \mathrm{l}$ of NucleaseFree Water (Invitrogen, USA) and incubation for 10 min at $60{ }^{\circ} \mathrm{C}$. Total RNA samples were kept at $-80{ }^{\circ} \mathrm{C}$ until subsequent analysis.

Preceding gene expression analysis, complementary DNA (cDNA) of the RNA samples was synthesized using SensiFAST ${ }^{\text {TM }}$ (Bioline, UK), following the manufacturer's instructions. From these, both the target and reference genes were amplified using the primers originally designed by Manjari et al. (2014) on Tarai Buffalo. The primer sequences were: For: 5'CTC GTCGATGGTGCTGACCAAG-3' and Rev:5' TCCTGTCCAGGCCGTAGGCGAT-3' for HSP70 and For: 5'-AGGTCATCCCTGAGCTCAACGG-3' and Rev: 5'TCGCAGGAGACAACCTGGTCCTCA-3' for GAPDH. Real-time polymerase chain reaction (RtPCR) was performed in triplicates with StepOnePlus ${ }^{\mathrm{TM}}$ Real-Time PCR System Thermal Cycling Block (Applied Biosystems, USA) employing the reaction mix and PCR profile used in the previous study of Maylem et al. (2018). Threshold cycles (Ct) of all the genes under study were recorded for analysis while the melting temperature was noted for validation. The Delta-delta method was implemented to determine the relative expression of the samples (Pfaffl, 2001)

\section{Western blot analysis}

The total protein, or lysate, was extracted from the semen samples after sonication with a filtered lysis buffer consisting of $50 \mathrm{mM}$ Tris, $150 \mathrm{mM} \mathrm{NaCl}$ and $1 \%$ Triton X-100 and Protease Inhibitor (SigmaAldrich, USA). Samples were then stored at $-80{ }^{\circ} \mathrm{C}$ until the following analysis.

Lysates were pre-heated at $95{ }^{\circ} \mathrm{C}$ for five minutes and mixed with 4x Laemmli buffer solution (Bio-Rad, USA) before the separation by gel electrophoresis. Separated proteins were transferred thereafter to Polyvinylidene flouride (PVDF) membranes and blocked with $5 \%$ Non-fat dried milk and $20 \%$ Tween 20 in PBS at $4{ }^{\circ} \mathrm{C}$. The membranes were incubated after with a Monoclonal Anti-HSP70 (Sigma-Aldrich,
USA) and Anti-GAPDH antibodies (Cell Signaling Technology, USA) overnight. They were washed three times with PBS-Tween 20 and incubated with a secondary antibody for two hours at $4{ }^{\circ} \mathrm{C}$. A colorimetric assay was then carried out using Opti4CN Substrate Kit (Bio-Rad, USA) for the detection of target proteins. Finally, a semi-quantitative analysis was performed on the detected protein bands using the Image Lab v.5.1 (Bio-Rad, USA) to determine the HSP70 relative protein value of each sample group.

\section{Immunolocalization}

A small volume $(500 \mu \mathrm{l})$ of semen samples were washed with PBS and fixed with $3.7 \%$ Paraformaldehyde (w/v) for $30 \mathrm{~min}$ at $4{ }^{\circ} \mathrm{C}$. Samples were then permeabilized with $0.1 \%$ PBS-Triton X-100 and incubated at room temperature for $10 \mathrm{~min}$. The sperm concentration was adjusted to $1 \times 10^{5}$ cells $/ \mathrm{ml}$ with PBS-Triton from which $10 \mu \mathrm{l}$ of the samples were taken and mounted on poly-L-lysin pre-coated glass slides. These were fixed by air drying at $37{ }^{\circ} \mathrm{C}$ and blocked with PBS containing 5\% goat serum (Sigma; PBS-GS) at $4{ }^{\circ} \mathrm{C}$. Afterward, the slides were incubated with a monoclonal anti-HSP70 antibody in PBS-GS overnight. This was immediately followed by the incubation with a secondary antibody, Alexa Flour ${ }^{\circledR}$ 555 goat anti-mouse IgG (Life Technologies, USA), for one hour. The slides were subsequently counterstained with Hoechst 33258 (Life Technology, USA) solution for $10 \mathrm{~min}$ and sealed with a coverslip using Fluoroshield ${ }^{\mathrm{TM}}$ with 1,4-Diazabicyclooctane (Sigma-Aldrich, USA). Using a fluorescent microscope (Nikon Ti, Nikon, Japan), the target protein was detected and visualized with a magnification equivalent to $40 x$.

\section{Statistical analysis}

The means of the relative HSP70 mRNA expression, relative protein value, and sperm motility were calculated and expressed in mean \pm SD in the results. Comparisons between sample groups were performed using T-test and Tukey's Post Hoc test at 0.05 level of significance in the JMP 13.0 (SAS Drive, North Carolina, USA) statistical software.

\section{Results}

The relative HSP70 mRNA expression and protein value in water buffalo semen were observed to differ significantly $(\mathrm{P}<0.05)$ between sample groups (Table 1). HSP70 expression was higher in the fresh semen 
group than the frozen group. It was initially measured up to $4.57 \pm 0.81$ in the samples but decreased by around fifty percent after the cryopreservation process $(\mathrm{P}<0.05$, Figure 1A). In contrast, the relative HSP70 protein value in semen increased considerably following the process. From $5.03 \pm 0.77$ in fresh semen samples, it increased by at least sixty percent in the frozen sample group $(\mathrm{P}<0.05$, Figure $1 \mathrm{~B})$

Table-1. HSP70 content and sperm motility of fresh and frozen group

\begin{tabular}{|c|c|c|c|}
\hline $\begin{array}{c}\text { Sample } \\
\text { Group }\end{array}$ & $\begin{array}{c}\text { Relative HSP70 } \\
\text { mRNA expression* }^{*}\end{array}$ & $\begin{array}{c}\text { Relative HSP70 } \\
\text { protein value }^{*}\end{array}$ & $\begin{array}{l}\text { Sperm } \\
\text { Motility (\%) }\end{array}$ \\
\hline Fresh & $4.57 \pm 0.81^{a}$ & $5.03 \pm 0.77^{b}$ & $61.27 \pm 12.46^{a}$ \\
\hline Frozen & $2.12 \pm 0.66^{b}$ & $7.55 \pm 0.91^{a}$ & $31.71 \pm 7.34^{b}$ \\
\hline
\end{tabular}

Means without a common letter differ significantly $(P<0.05)$. "Relative measures of HSP70 have no unit.
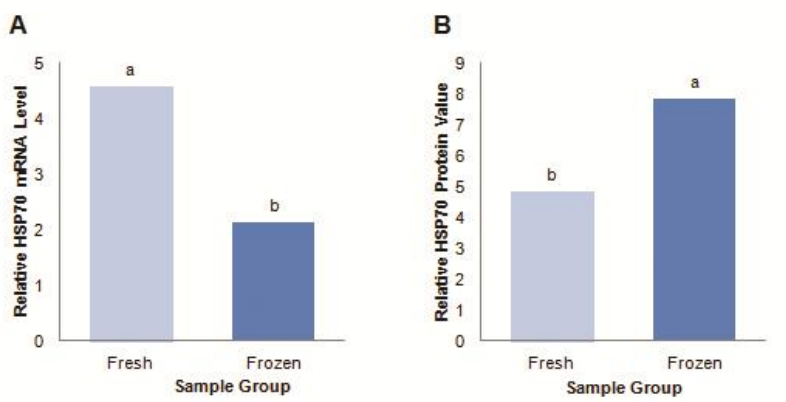

Figure-1. Relative HSP70 mRNA level (A) and protein level (B) in Fresh and Frozen sample groups.

There was also a shift in the cellular localization of the HSP70 protein in water buffalo spermatozoa after cryopreservation. It initially appeared as a thick, slightly angled line at the middle of the fresh sperm head, an area known as the equatorial segment (Figure 2A). It was also detected as a well-defined line in the sperm tail, that extended from the mid-piece to the end-piece. In the Frozen sample group, only this tail signal was retained. The head fluorescent pattern of HSP70 was altered and replaced by a granular, round signal at the post-acrosomal region (Figure 2B).

Similarly, the sperm motility significantly differed between the two sample groups. The $61.27 \%$ average sperm motility recorded in the fresh sample group was reduced to $31.71 \%$ in the frozen sample group after freeze-thawing $(\mathrm{P}<0.05$, Figure 3$)$.

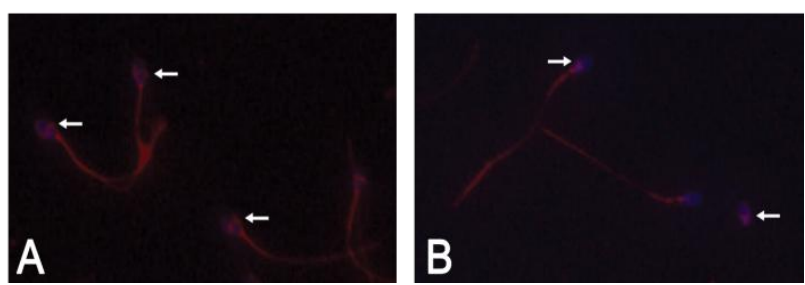

Figure-2. Localization of HSP70 in Fresh (A) and Frozen (B) spermatozoa of water buffalo.

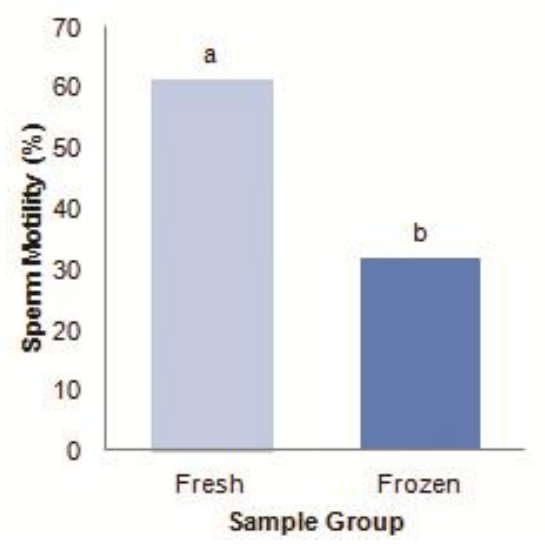

Figure-3. Mean sperm motility of Fresh and Frozen semen sample groups.

\section{Discussion}

The cryopreservation process appeared to have opposite effects on the transcript and protein level of HSP70 in water buffalo spermatozoa: the HSP70 mRNA level declined while the protein level increased. These findings suggest an induction of HSP70 protein synthesis in the sperm samples during the process, wherein the HSP70 mRNA was likely consumed. Since spermatozoa lose their potential for transcription at maturity and could no longer carry out gene expression (Boerke et al., 2007), the lost HSP70 mRNA in the samples could not be replaced. This inevitably led to a significant drop in its level. On a different note, the rise in HSP70 protein level was unprecedented in frozen spermatozoa. Previous works on semen cryopreservation generally described a significant decrease in sperm protein levels. An earlier study on water buffalo even recorded a $55 \%$ reduction in HSP70 protein after cryopreservation. The decrease in protein level therein was attributed to the processrelated degradation (Varghese et al., 2016). A Similar indication of protein translation was only discovered in the spermatozoa undergoing sperm capacitation. 
During this modification, nuclear-encoded mRNAs were translated into proteins by mitochondrial-type ribosomes to replace damaged ones and/or fulfill the particular needs of the sperm (Gur and Breitbart, 2003).

As for its cellular localization, HSP70 protein was initially detected at the equatorial segment of the sperm head in the Fresh sample group. This area acts as the reservoir of molecules in the cells that are transferring from one region of the sperm head to another (Gadella et al., 1994). It presents a convenient position for HSP70 to mediate its role in the translocation of other polypeptides (Arispe et al., 2002; Craig, 2018). Among artiodactyls, the cellular localization of HSP70 protein in fresh spermatozoa varies greatly and only the boar semen displayed a comparable fluorescent pattern. It appeared triangular under higher magnification in the same area in pig spermatozoa (Spinaci et al., 2005). In other species such as cattle and horses, the fluorescent pattern was detected in the acrosomal and post-acrosomal regions respectively (Kamaruddin et al., 2004; Volpe et al., 2008).

After cryopreservation, the cellular localization of HSP70 protein in frozen water buffalo spermatozoa shifted. The process was known to generate multiple stresses in the cell that can trigger the redistribution of HSP70 protein and its proper functioning to a different location (Guerriero and Raynes, 1990; Volpe et al., 2008). Hence, in frozen spermatozoa, the localization of HSP70 protein was moved to the post-acrosomal region of the sperm head. This region typically holds specific antigens associated with gamete interaction (Matwee et al., 2001). It seemed like a rather appropriate position for HSP70 protein in spermatozoa, considering that the protein served as an important binding site during sperm-egg recognition (Matwee et al., 2001). Other studies even speculated that due to its significance, it might even undergo an exposition to the sperm surface (Spinaci et al., 2005). This new localization of HSP70 protein in frozen samples matched the position of the protein in vitro capacitated boar spermatozoa (Spinaci et al., 2005). It appeared to concur with the earlier observations and likewise indicate a resemblance between cryopreservation and capacitation on their effect on the HSP70 protein in the sperm.

Meanwhile, a decline in the sperm motility of water buffalo spermatozoa was also documented after cryopreservation. Semen quality, in general, could decrease up to $40-50 \%$ after freezing and thawing $(\mathrm{Hu}$ et al., 2011), specifically the sperm motility of frozen samples was lowered compared to the fresh sample group (Andrei, 2009). This loss in sperm movement seemed to be related to the change in the expression of HSP70, as though the exhaustion of HSP70 mRNA favored the attenuation of motility. Similarly, the decline in the motility of bovine spermatozoa was found to be proportional to the gradual decrease in HSP70 mRNA level at different stages of freezing (Zhang et al., 2015). In pig spermatozoa, as well, the reduced motility of some sample groups was linked to the significantly low level of HSP70 protein (Huang et al., 2000).

During cryopreservation, an underlying event is commonly induced that greatly mirrors the effect of capacitation on the sperm (Cormier and Bailey, 2003; Talukdar et al., 2016). This event is widely referred to as 'capacitation-like' and elicits the same ultrastructural and biochemical modifications in frozen spermatozoa like elevated metabolic rates, lipid peroxidation, uncontrolled calcium influx, and an increased tendency for acrosome reaction (Cormier et al., 1997; Brum et al., 2008; Talukdar et al., 2015). It is however completely different and separated from the capacitation process in vitro (Thomas et al., 2006; Naresh and Atreja, 2015). The changes on HSP70 presented above that reflected the effects of sperm capacitation could be the manifestations of the capacitation-like event in cryopreservation. Indeed, this can substantiate the induction of protein translation in spermatozoa because the increase in the calcium level during the capacitation-like event can promote the synthesis of HSP70 protein (Khanna et al., 1995). It can also explain the decline in the sperm motility observed in the results since the resulting cellular modifications often lead to the loss of different sperm attributes (White, 1993; Harrison, 1996). Hence, it may be necessary to eliminate the capacitation-like event from the cryopreservation process to alleviate this effect and improve the postthaw quality of the spermatozoa (Longobardi et al., 2017; Reddy et al., 2018, Hezavehei et al., 2018). Future studies should revisit the current techniques in buffalo semen cryopreservation and seek various ways to integrate the control of the event for optimization strategies.

\section{Conclusion}

In sum, the present study reported the changes induced by the cryopreservation process on the HSP70 of water 
buffalo spermatozoa. It revealed the capacitation-like event that underlay the process and discussed its implications on the HSP70 protein itself and sperm cells in general. The findings of this study offered a new perspective to the buffalo semen cryobiology and a potential approach in improving the cryopreservation process.

\section{Acknowledgement}

The authors would like to acknowledge the technical assistance and administrative support received throughout the conduct of this study from the Livestock Biotechnology Center and the Philippine Carabao Center National Headquarters and Genepool.

Disclaimer: None.

Conflict of Interest: None.

Source of Funding: The financial support for this study was provided by the Department of Agriculture, Philippines through the Biotechnology Program Office and Philippine Carabao Center National Headquarters and Genepool.

\section{References}

Andrei SMH, 2009. Factors affecting the quality of cryopreserved buffalo (Bubalus bubalis) bull spermatozoa. Reprod. Domes. Anim. 44: 552-569.

Arispe N, Doh M and De Maio A, 2002. Lipid interaction differentiates the constitutive and stress-induced heat shock proteins HSC70 and HSP70. Cell Stress Chaperone. 7: 330-338.

Boerke A, Dieleman SJ and Gadella BM, 2007. A possible role for sperm RNA in early embryo development. Theriogenol. 68: S147-S155.

Brum AM, Sabuer K and Ball BA, 2008. Apoptotic-like changes in equine spermatozoa separated by density gradient centrifugation. Theriogenol. 69: 1041-1055.

Cao WL, Wang YX, Xiang ZQ and Li Z, 2003. Cryopreservation-induced decrease in heat-shock protein 90 in human spermatozoa and its mechanism. Asian J. Androl. 5:43-46.

Cormier N, Sirard MA and Bailey JL, 1997. Premature capacitation of bovine spermatozoa is initiated by cryopreservation. J. Androl. 18:461-468.

Cormier N and Bailey JL, 2003. A differential mechanism is involved during heparin- and cryopreservationinduced capacitation of bovine spermatozoa. Biol. Reprod. 69:177-185.

Craig EA, 2018. Hsp70 at the membrane: driving protein translocation. BMC Biol. 16:1-11.

Ellington JE, Samper JC, Jones AE, Oliver SA, Burnett KM and Wright RW, 1999. In vitro interactions of cryopreserved stallion spermatozoa and oviduct (uterine tube) epithelial cells or their secretory products. Anim. Reprod. Sci. 56:51-65.

Gadella BM, Gadella TW, Colenbrander B, van Golde LM and Lopez C, 1994. Visualization and quantification of glycolipid polarity dynamics in the plasma membrane of the mammalian spermatozoon. J. Cell. Sci. 107: 2151-2163.

Guerriero V and Raynes AD, 1990. Synthesis of heat shock proteins in lymphocytes from livestock. J. Anim. Sci. 68: 2779-2783.

Gur Y and Breitbart H, 2003. Mammalian sperm translated nuclear-encoded proteins by mitochondrial-type ribosomes. Genes Dev. 20: 411-416.

Harrison RA, 1996. Capacitation mechanisms, and the role of capacitation as seen in eutherian mammals. Reprod. Fertil. Dev. 8: 581-594.

Hezavehei M, Sharafi M, Kouchesfahani HM, Henkel R, Agarwal A, Esmaeili V and Shahverdi A, 2018. Sperm cryopreservation: A review on current molecular cryobiology and advanced approaches. Reprod. Biomed. Online. 37(3): 327-339.

Holt WV, Del Valle I and Fazeli A, 2015. Heat shock protein A8 stabilizes the bull sperm plasma membrane during cryopreservation: Effects of breed, protein, concentration, and mode of use. Theriogenol. 84(5):693-701.

Hu JH, Zhao XL, Tian WQ, Zan LS and Li QW, 2011. Effects of vitamin $E$ supplementation in the extender on frozen-thawed bovine semen preservation. Animal. 5:107-112.

Huang SY, Kuo YH, Lee YP, Tsou HL, Lin EC, Ju CC and Lee WC, 2000. Association of heat shock protein 70 with semen quality in boars. Anim. Reprod. Sci. 63: 231-240.

Kamaruddin M, Kroetsch T, Basrur PK, Hansen PJ and King WA, 2004. Immunolocalization of heat shock protein 70 in bovine spermatozoa. Andrologia. 36: 327334.

Khanna A, Aten RF and Behrman HR, 1995. Physiological and pharmacological inhibitors of luteinizing hormonedependent steroidogenesis induce heat shock protein70 in rat luteal cells. Endocrinol. 136:1775-1781.

Longobardi A, Albero G, De Caditiis C, Salzano A, Natale A, Balestrieri A, Neglia G, Campanile G and Gasparrini B, 2017. Cholesterol-loaded cyclodextrins prevent cryocapacitation damages in buffalo (Bubalus bubalis) cryopreserved sperm. Theriogenol. 89:359364.

Mamuad F and Venturina E, 2013. Development of Frozen 
Buffalo Semen Production in the Philippines. Buffalo Bull. 32(2):392.

Manjari RM, Yadav K, Ramesh S, Uniyal S, Rastogi SK, Sejian V and Hyder I, 2014. HSP70 as a marker of heat and humidity stress in Tarai buffalo. Trop. Anim. Health Prod. 47:111-116.

Matwee C, Kamaruddin M, Betts DH, Dasur PK and King WA, 2001. The effects of antibodies to heat shock protein 70 in fertilization and embryo development. Mol. Hum. Reprod. 7: 829-837.

Maylem ERS, Rivera SM, Leoveras MADC, Venturina EV, Atabay EP and Atabay EC, 2018. Thermotolerance identification in water buffalo using heat shock protein 70 (HSP70) and its effect to semen quality in varying environmental conditions. Philipp. J. Vet. Anim. Sci. 44(1): 22-31.

Mohamad SFS, Ibrahim SF, Ismail NH, Osman K, Jaafar FHF, Nang CF and Yusof FZM, 2018. Quantification of HSP70 gene expression and determination of capacitation status of magnetically separated cryopreserved bovine spermatozoa at different thawing temperature and time. Sains Malays. 47(6):1101-1108.

Morris GJ, Acton E, Murray BJ and Fonseca F, 2012. Freezing injury: the special case of the sperm cell. Cryobiol. 64:71-80.

Naresh S and Atreja SK, 2015. The protein tyrosine phosphorylation during in vitro capacitation and cryopreservation of mammalian spermatozoa. Cryobiol. 70(3):211-216.

Nixon B, Bromfield EG, Dun MD, Redgrove KA, McLaughlin EA and Aitken RJ, 2015. The role of molecular chaperone heat shock protein A2 (HSPA2) in regulating human sperm-egg recognition. Asian J. Androl. 17:568-573.

Olszewska-Slonina D, 2013. Sperm cryopreservation and oxidative damage. What does it mean? Cent. Eur. J. Urol. 66: 50-51.

Pfaffl MW, 2001. A new mathematical model for relative quantification in real-time RT-PCR. Nucleic Acids Res. 29: e45.

Pini T, Leahy T and de Graaf SP, 2018. Sublethal sperm freezing damage: manifestations and solutions. Theriogenol. 118(15):172-181.

Rajoriya JS, Prasad JK, Ghosh SK, Perumal P, Kumar A, Kaushal $S$ and Ramteke SS, 2014. Studies on effect of different seasons on expression of HSP70 and HSP9O gene in sperm of Tharparkar bull semen. Asian Pac. J. Reprod. 3(3): 192-199.

Reddy VS, Yadav B, Yadav CL, Anand M, Swain DK, Kumar D, Kritania D, Madan AK, Kumar J and Yadav S, 2018. Effect of sericin supplementation on heat shock protein 70 (HSP70) expression, redox status and post thaw semen quality in goat. Cryobiol. 84:33-39.

Spinaci M, Volpe S, Bernardini C, De Ambrogi M, Tamanini C, Seren E and Galeati G, 2005. Immunolocalization of heat shock protein 70 (HSP 70) in boar spermatozoa and its role during fertilization. Mol. Reprod. Dev. 72:534-541.

Talukdar DJ, Ahmed K and Talukdar P, 2015. Cryocapacitation and Fertility of Cryopreserved Semen. Int. J. Livest. Res. 5(6):11-18.

Talukdar DJ, Ahmed K, Deka BC, Sinha S, Deori S and Das GC, 2016. Cryo-capacitation changes during cryopreservation of swamp buffalo spermatozoa. Indian J. Anim. Sci. 86(4):397-400.

Thomas AD, Meyers SA and Ball BA, 2006. Capacitationlike changes in equine spermatozoa following cryopreservation. Theriogenol. 65: 1531-1550.

Varghese T, Divyashree BC, Roy SC and Roy KS, 2016. Loss of heat shock protein 70 from apical region of buffalo (Bubalus bubalis) sperm head after freezing and thawing. Theriogenol. 85: 828-834.

Volpe S, Galeati G, Bernardini C, Tamanini C, Mari G, Zambelli D, Seren E and Spinaci M, 2008. Comparative immunolocalization of heat shock proteins (HSP0) -60, -70, -90 in boar, stallion, dog and cat spermatozoa. Reprod. Domest. Anim. 43: 385-392.

Watson PF, 2000. The causes of reduced fertility with cryopreserved semen. Anim. Reprod. Sci. 60-61:481492.

White IG, 1993. Lipids and calcium uptake of sperm in relation to cold shock and preservation: a review. Reprod. Fertil. Dev. 5:639-658.

Zhang XG, Hong JY, Yan GJ, Wang YF, Li QW and Hu $\mathrm{JH}, 2015$. Association of heat shock protein 70 with motility of frozen-thawed sperm in bulls. Czech J. Anim. Sci. 60(6): 256-262.

\section{Contribution of Authors}

Maylem ERS: Designed the experimental study, applied for the research fund, conducted the statistical analysis and prepared the draft of the manuscript

Rivera SM: Conducted the study and prepared the manuscript draft

Ramos GE \& Venturina EV: Conducted the study Atabay EC: Applied for the research fund and supervised the study Atabay EP: Applied for the research fund, supervised the study and approved the final version of the manuscript draft 